Journal of Law \& Social Studies (JLSS)

Volume 1, Issue 2, pp 77-89, 2019

www.advancelrf.org

\title{
LANDSCAPE OF LAWS AND PROCEDURE OF WINDING UP OF COMPANIES IN PAKISTAN
}

\author{
Rehmat Ali \\ Additional District \& Sessions Judge Lahore, \\ Presently serving as Judge of GBV Model Court Lahore \\ E-mail: malikrehmatali@gmail.com
}

\begin{abstract}
Under the Company Law of Pakistan the winding up process through Court is regulated under sections 293, 305, 306 and of new Companies Act 2017. Nonetheless, the main focus of the courts is "to save the corporate sector" on the ground that it is "just and equitable" under Section 301 of Act, that a company should be put to winding up proceeding or not and there is no other mode to avoid the winding up of the companies like providing financial assistance. However, a radical change has been introduced in the world, in the field of windings up of the companies since the incorporation of the companies in Pakistan. Firstly we followed Companies Act 1913 and secondly a company ordinance 1984 promulgated and recently Companies' Act 2017 has been introduced but no substantial change has been introduced in winding up proceeding of the companies. In the wake of the present mechanism and corporate legal framework in Pakistan, it is endeavored to research whether, in view of modern corporate cultures prevalent in the world, the Companies Act, 2017 provides adequate measures for the companies sought to be wound up in Pakistan. This article also aims, inter alia, to analyze the new techniques prevalent in various jurisdictions of the world and consider the aspects of legislative transplant of the same within the corporate legal system of Pakistan.
\end{abstract}

Keywords: winding up, rescue measures, just and equitable, role of courts, financial assistance, comparative jurisprudence.

\section{Introduction}

Winding up of a company's affair is a mechanism in which management of a company; its affairs and its assets are taken out of the hand of directors and company management and handed over to the liquidator. Its liabilities are meet out from the assets of company and surplus id returned and distributed to share-holders according to scheme of memorandum or article of association. It is a famous principle of English Company Law that once a company incorporated under the law, can only be put to an end in the manner prescribed by law and by the exercise of statutory powers prescribed there under.

The term "winding up" as applied to the companies is derived from a suit for the analogous purposes of winding up and dissolving of a partition. The term "winding up" has also been defined by Martha Bruce in the following terms "Where the company for whatever the reason is, not able or permitted to continue in operation, application can be made to the court for the company to place a liquidation (known as winding up)."

The concept of winding up of a company law in Pakistan is closely linked with the company law development in England. In the UK, the Companies Act 1985, winding up and insolvency proceedings were part of the same Act, but subsequently on the legislation of Insolvency Act 1986 all the insolvency and winding up proceedings were included in this Act and section 501 to 660 of Companies Act 1985 was repealed. In Pakistan to continue the corporate practices, the Companies Act 1913 was implemented with certain amendments and subsequently this Act was repealed by the Companies Ordinance 1984. In the Companies Ordinance 1984 no definition of winding up has been provided rather mode of winding up has been mentioned in Ordinance.

In order to create a strong and sustainable corporate culture in the country, it is necessary to provide favorable circumstances for corporate activities. There is favorable investment atmosphere in U.S.A and the U.K in term of remedies; the investors are willing to invest their capital there. In the U.K Company Voluntarily Arrangements 
(CVAs), a work out plan, scheme of arrangement and administration mechanisms are very useful and aimed at promoting corporate insolvency regime. On the other hand in United States (U.S.A), a corporation suffering from financial distress can take advantage of Chapter-11 of Bankruptcy code 1978.

The main object of theses is to protect the rights of members and stake holders in the company and the property of the company in case of winding up. Different countries have adopted different mechanism to rescue the financially distressed and insolvent company to make it a useful and profitable concern rather put it into liquidation and winding. For this purpose, Rehabilitation Act has been passed for the assistance of sick and distress companies.

\section{Development of Winding Up Law in Pakistan}

Once a company has been incorporated and certificate of incorporation has been issued and declared as a separate legal entity being an artificial person, then its rights should be equal to the rights of natural person. When a process for creating a legal personality or legal entity has been developed or taken into the existence after a long development of the law and particularly decisions of the Courts, it is very painful to make its dissolution being a legal entity. The most important mode of winding up by court is called Just and Equitable to dissolve the company. Its development will also be discussed later on. Superior courts in Pakistan have made significant role in development of the concept of "just and equitable ground" for a company, going into liquidation. The basic aim of winding-up of a corporation is to release assets of a company for its payment of debts in accordance with law in winding-up cases. Utmost endeavor should be made for the survival of the corporate sector rather than to dismantle it.

The Joint Stock Companies Act, 1844 was passed by Parliament of England. It provided a sophisticated method of winding up of a company under liquidation. The concept of "voluntary winding-up" by the courts was first time introduced by The Companies Act 1862. There after rule of official receiver and liquidator and their rights and duties was injected by the Company (Winding-up) Act, 1890. First time difference between the voluntary winding-up by the members and creditors was incorporated by Companies Act 1962. The first legislation which introduces comprehensive and complete mechanism of winding up was the Companies Act 1948. the insolvency provision was present in the Companies Act 1985, but after the promulgation of Companies Act 1986 sections 501 to 650 dealing with the process of winding up were made part of Insolvency Act which was a complete law dealing with insolvency matters.

Although the historical development as mentioned above even prior to creation of Pakistan have no direct relevance to the present Companies Act, 2017 but it is indeed very important to trace the principles of Corporate Law on the above mentioned Act because we inherited the law from British and thereafter followed them with certain changes according to the circumstances of the country. So, we have almost same principles as has been followed in England. It is worthwhile to mention here that no substantial amendments in the context have been made so for which might be helpful to regulate winding up regime in Pakistan even in Companies Act 2017.

\section{Role of Courts in Development of Winding Up Law}

Superior courts in Pakistan have played an important role while interpreting the grounds of winding up of companies in Pakistan and they have also protected the corporate sector providing guidelines. Supreme Court of Pakistan has laid down the principles regarding the winding up petitions.

Following are the guidelines for the winding up of companies in Pakistan:

1- That if a debtor company is merely unwilling to pay its debts but otherwise is commercially solvent, then the normal remedy available to a creditor is a suit for the recovery of amount and not a petition for winding up. If there is bona fide dispute between creditor and the debtor company, the remedy in shape of suit for recovery will be available and not application for winding up of company.

2- That clause of subsection 306 of the Ordinance raises presumption as to the fact that the "company is deemed to be unable to pay its debts" after receipt of notice and fail to pay within 30 days of the notice in despite of the receipt of demand in terms of the above clause. This presumption can be rebutted by the company by showing the reasonable cause and proving that the company is going concern and can pay outstanding amount against it.

3- These sections 305 and 306 of Ordinance cannot be used a tool to pressurized a company to pay its debit to unpaid creditor but to facilitate the continuation of the company and its business if same has ceased to be solvent.

4- That though under section 9(3) of the Ordinance it is permissible to adopt summary procedure, the procedure adopted should be fair and just which may ensure equal opportunities to the contesting parties. 
5- That the effect of lack of proof of a demand notice by a creditor in term of clause (a) of subsection 306 of Ordinance is the presumption that the debtor was not in a position to repay its debts will not be available in a petition for winding up, but the creditor will be at liberty to substantiate its claim that company is not in a position to repay its debt. Under above mentioned law.

6- That through the remedy provided under clause (a) of subsection(1) of section 306 of the Ordinance is independent but it is not binding on company judge but it is the discretion of court to allow petition of winding or not keeping in view the attending circumstances of each case. The approach should be to see that a commercially insolvent company ceases to operate and not to provide a forum for the recovery for certain amount or a particular creditor

7- That in order to determine whether a debtor company is commercially insolvent, it should not be considered those assets without which company cannot operate its business activates, but amount available to the debtor company, or which may become available in normal course of business without disposing of the above assets will have to be taken into consideration.

8- That the factum that other remedies are available to creditor in general as well as under special law cannot prevent him from seeking relief under this law seeking winding up of company

9- Whether the debtor company is unable to pay debts can be established from the company`s present and future liabilities instant payable debts.

\section{Rationale behind Winding Up of a Company}

The purpose of winding-up is to:

a. If possible all the creditors should be treated equally as provided under the law.

b. $\quad$ Distribute the property of the company to the members, according to their rights;

c. Realize the assets of the company and pay its debts expeditiously as provided by law.

d. Disallow the companies, which are no more commercially solvent, to conduct business.

It is time and again held by the court that object of winding-up is not a tool to pressurize any company for payment outstanding against him but stop the business activates of company which not commercially solvent in order to effect actual realization at the end. When company is placed in a position from where it is not possible for company to pay its debt, it can be considered a ground for winding up and unanimous opinion of creditors that if the matter is left any further then their security as well as will amount due to them will be at risk.

\section{Modes of Winding-Up of a Company}

The Companies Act 2017, provides following modes of winding-up

According to Company Act, 2017 a company can be wound up under the supervision of the court, it can be termed as "compulsory winding-up". In such like cases when a petition is filed it deemed to be wound up. According to Companies Act 2017, following moods have been provided for winding up of a company which is as under:

1- Company may be wound up by special resolution, but where it is against the interest of public company then this discretion cannot exercised for winding up of the company.

2- In the land mark judgment Harmer Ltd. (1959), where Mr. Harmer, having controlling shares in the company was not properly running business because of his superannuation, the court, on the petition of sons, held it to be oppression and mismanagement and ordered the winding-up of the company. The remedy in shape of oppression and mismanagement have wide scope as compare to other remedies because it protects the interest of the creditors, as well as make a check on the conducts which is against interest of the public at large, in such like situation remedy is provided by the Companies Act, and court has held that public money taken from company in a clandestine manner come under the ambit which constitute oppression and mismanagement and against the public interest. There are also other instances where the petition of winding-up was dismissed due to lack of qualifying shares.

3- If a business is being carried out against the article and memorandum of association of the company then it is a valid ground for winding up as in case titled "Fida Ali Yousaf v. Grazalt Refineries Ltd", it was observed when main object of the company ceased to exist and majority share-holders are defrauded then court may order for winding up of the company.

4- If a business is being carried out against the article and memorandum of association of the company then it is a valid ground for winding up as in case title "PSO Co. Ltd. V. Pak. O.P. Ltd", although petitioners could not satisfactorily establish that respondents (Directors) had not properly maintained accounts of the Company, yet the fact that respondents were in collusion with each other and with third parties to oust petitioner (who was holding $50 \%$ share 
capital) had committed scam, misfeasance and malfeasance in performing and conducting day to days affaires of the company as contemplated under Section 305.

5- According to Companies Act, 2017 if a company is unable to pay its outstanding liabilities like debt to the creditors it will be presumed that company is unable to pay its debt and court can pass an order for its winding up. Instead of paying debts, profits were applied to some other use, such conduct was deemed to be inability of company to pay debt as contemplated by Section 306.

6- It is requirement of the law certain meetings as provided in companies act, should be held within specific time violation thereof will create legal bar on the for commencing its business. It was held in the case "Asmatullah $V$. Court of Summary Trial", where default was made in in fulfilling the mandatory requirements of law regarding convening statutory meeting in such cases, if it is submitted before court any sufficient cause for not holding statutory meeting court may extend the time and if again company failed to obey the directions then court would wind up company.

7- It is requirement of la w that after issuance of certificate of incorporation a company is failed to commence its business within one year for suspended its business for one year it can be a ground for winding up. In case of "Integrated Technologies \& Systems Ltd. V. Interconnect Pakistan (Pvt.) Ltd, chief," executive of the company was alleged to have diverted the funds of the company to his personal account, which was proved, followed by winding-up.

8- There is requirement of number of persons for every type of company including listed, private, public and single member company. If the number of its members are reduces are provided in law then this is one of the ground for winding up.

9- It is settle proposition of law that if a particular thing should be done in a particular manner then it should be done in that manner violation thereof will be nullity in eye of law. In same manner if the company is failed to comply with the direction of court or SECP and management of company have refused to act upon the requirements of memorandum and article of association of Company it may be wound up in such circumstances.

10- In case of listed company same has ceased to be listed company therefore liquidator will be appointed and affairs of company will be taken from the hands of directors and will be given to liquidator.

11- The most important ground for winding up of the company is equitable remedy in shape of just and equitable. This rule provides vast powers to court dealing with winding up proceedings. If according to circumstances court is of view that company should be wound up just because it is equitable in such circumstances then court can make an order for winding up accordingly. A lot work has been done on this topic particularly by law courts in order to reshape the law of winding up.

\section{Voluntary Winding-Up}

Voluntary winding-up is of two kinds;

a. Members' Voluntary Winding-Up: The pronouncement of solvency has to be made under section 362 of the Companies Ordinance. It is necessary in case of members voluntary winding up it will take effect from the date when resolution of winding up will be passed.

b. Director's Voluntary Winding-Up: In case of director's voluntary winding up, the directors are required to make announcement, by majority, under the affidavit, to the effect that, they have made full inquiry regarding affairs of company and they have numinous opinion that company has no debt or that it will be able clear it debt within stipulated period.

\section{Winding-Up Subject to Supervision of the Court}

The court may pass an order for winding-up of company subject to supervision of the court after passing of resolution for voluntary winding up. Additional liquidator or liquidators may be appointed by the court and court may remove any liquidator. Both voluntary and winding up by the court, will be governed by the order of supervision of the court.

\section{Winding-Up on the Report of Inspector}

The Companies Act 2017 provides that if it appears to the Commission (SECP) from any report made by the Inspector that it is appropriate that a company should wound up, the Commission shall present the report before court by the registrar or any person authorized person in this behalf.

An Application for the winding-up of the company on just and equitable grounds can be filed u/s 290 of Companies Act, 2017 for winding of a company on just and equitable ground. 


\section{Winding-Up on the Scheme of Amalgamation or Reconstruction}

In the case of Capital Assets Leasing Corporation Ltd V. International Multi Leasing, when there is no chance of compromise then the court may order winding-up and this will fall under Section 305 of the Companies Ordinance 1984.

\section{Winding-Up on the Report of Registrar or any other Concerned Person:}

A company or by any creditor or creditors or by any contributory or contributories or by all or any of the aforesaid parties, together or separately or by the registrar or by the SECP or by a person authorized by the Authority in that behalf, can file a petition for winding up under the company law.

\section{Striking off from the Register of Companies}

Company law empowers the registrar to wind up a company after advertisement of inquiries that the company is not functioning in lawful manner or against its object clause or failed to file accounts and returns as required by law.

\section{Winding-Up on Just And Equitable Grounds}

The mode of winding up of just and equitable ground is a concept based on law of equity developed in England in $18^{\text {th }}$ century to overall the procedural defects present in common law system. The object of this law was to provide justice to the people according to fairness and natural law apart from procedural technicalities prevalent in common law system. Just and equitable ground is a relative term may vary from case to case and circumstances of the matter, in this way only courts of law are considered the best judges to access the condition, circumstances and facts of the case to apply this ground for winding up of a company. It is a sole power of the court to decide that it is just and equitable ground for winding up of a company.

In case of Ali Woolen Mills Ltd V I.D.B.P, where there is continuous loss in business of company and sections of company are running in loss for considerable period it was considered a valid ground for winding-up on "just and equitable ground". There are some traditional grounds which courts regards "adjust and equitable" for winding up of a company, including situations where corporation was promoted fraudulently; where there is deadlock over company's management decisions; where there is mismanagement and oppression on the part of management to run the affairs of the company; where main object of company has gone etc.

Companies Act, 2017 provides remedy for filling petition for winding-up if any stake-holder thinks that is a situation which warrants the interference of the court on just and equitable ground. It is sole discretion of the court to see whether there is sufficient ground for winding-up on this ground or not. Court can adjourn the case with or without conditional order for winding-up as it think fit according to circumstances of the case.

The remedy provided under the equitable relief can only be exercised when there is no alternative remedy in general law. Equitable remedy is governed by law of and general remedy is regulated by the general law. In case of Trade And Industry Publication Ltd V. IDBP, when a petition under Section 314(2) was filed with prayer that company be woundup on the ground of "just and equitable" but court law after considering all facts and circumstances refuse to accept the petition on the ground that alternative remedy is available to the petitioner. Supreme Court of Pakistan also passed a conditional order in winding up of appeal and dismisses the appeal with the observation in the case the appellant deposits the mobilization bond amount, namely, Rs. 1, 26, 00,000/- payable to the respondent within the period of 6 months, the winding up order will stand set aside. In case of default, it will remain in field and it will be deemed to have been maintained.

If the court considered that the winding up order is against the interest of creditors and members; the court may make specific direction to the management of the company to take control of day to day affairs of company; main issue or bone of contention be removed; propose specific alteration in management of the company.

When order is passed on winding up by the competent court of law then it is intimated to all the stake-holders.

\section{Effects of Winding Up Order}


The company Act provides that after the passing of winding-up order any transition regarding sale and purchase of shares will be nullity in eye of law. It will take effects against all the creditors, contributories other stake-holders equally as it if made on joint application.

A- Any transfer of shares without the sanction of the liquidator will have no legal value.

B- Once a winding-up is announced then subsequent change with respect to status of member of company will be of no effect.

C- After commencement of "winding-up proceedings", all sorts of transactions made without the sanction of the court in respect of the company's assets shall be void except in case of beneficial winding-up.

D- After commencement of "winding-up proceedings", any proceeding enforcing any right shall be void if made without the sanction of the court. Moreover after order of winding-up all the legal proceedings against the company will be stopped except with the permission of the court.

\section{Jurisdiction of the Court and Stay of Proceedings}

The Company Act provides that matter relating to winding-up any suit for and against the company will maintainable before Honorable High Court. Whereas territorial is concerned it will be determined from the place of registered office of the company. Once an order of winding-up is passed by the competent court of law it can only be revoked by the same court but for this purpose certain conditions precedents has been imposed by the law, firstly, this petition be filed within 3 years from the commencement of winding-up order, secondly, by the creditors, contributors or registrar or authorized person on this behalf, thirdly, this petition should be accompanied by the proof to the satisfaction of the court that it is appropriate for staying, withdrawing, revoking the winding-up order or on such terms and conditions as the court think fit, as in a case of "Consolidated Exports Ltd. V. Dyer Textile and Printing Mills Ltd". Court observed that it has powers to stay winding-up proceedings altogether or on such grounds which are sufficient as court think appropriate.

According to The Companies Act, 2017 if winding-up order has been passed company continued till the final dissolution order by the court. In case of "Syndicate Bank v. Printers all P. Ltd" the court nevertheless ordered winding-up.

\section{Preferential Payments:}

There are certain payments mentioned in law which are called preferential payments which are to be paid in prior to all other debts which are as under:

1. Any tax, other duties payable to Federal, Provincial and Local Governments.

2. All wages or salary of any employee.

3. Insurance contribution.

4. Compensation to heirs of employees in case of his death or disability.

5. Payments due out of provident fund, pension fund.

6. Expenses of investigation, if any.

\section{Just and Equitable Grounds in Pakistan}

In The Companies Act, 2017 "A company may be wound up by the Court, if the Court is of opinion that it is "just and equitable" that the company should be wound up. The ground of "just and equitable" is product of law of equity developed in UK in order to supplant the procedural defects of common law. Both two systems continued side by side for a long time and after Judicature Act, some principles of law of equity was included in common law there after one system was carried on. With this background we can see there are equitable principles present in English system in shape of equitable reliefs. These reliefs can only be sought when there is no other relief in general law. It is powers of the court to see what grounds constitute the ground of "just and equable" while exercising the discretion and this discretion should be exercised according to sound judicial reasoning without prejudicing the rights of parties. So, the court while deciding for issuing the order for winding-up a company on "just and equitable" grounds must be cautious in its handling of the case so as to avoid any injustice and for betterment of the corporate sector.

Generally there are two reliefs available to the petitioner one is general remedy provided under general law other is equitable remedy provided by law of equity enshrined in law by law of equity. It is command of law that in presence of alternative remedy provided under general law equitable relief cannot seek for. So in case of winding-up the remedy 
of winding-up on just and equitable ground petitioner has to satisfied to the court that there is no other alternative remedy available to him. The alternative remedy in this respect has been provided under section 290 of the Companies Ordinance 1984.

Same case with Insolvency Act 1986 of UK it clearly bar the petition of winding-up on just and equitable ground in presence of alternative remedy in the opinion of the court that petitioner are not approaching at relevant forum. As in of case of "Trade And Industry Publication Ltd V. IDBP", when a petition under Section 314(2) was filed before the court on the ground of just and equitable but court of law refused to pass an order on the ground that alternative remedy is available to petitioner. The question whether it is appropriate to wind-up the company on just and equitable ground is matter of fact which must be answered on the facts, which exist at the time of winding-up; it must be based upon subsisting facts and not upon past practice.

A special mechanism regarding winding-up on just and equitable has been provided by Companies laws in Pakistan. It is on the report of inspector after detailed investigation and the Commission (SECP) has sufficient material on record to proceed on and it is firm view of the commission to initiate proceedings and therefore commission will authorize the registrar or any other representative in this behalf to file application on just and equitable ground. U/S 285, "if the scheme of arrangement, amalgamation, reconstruction or compromise is not workable the court may order windingup having the same effect as that of winding-up under Companies Ordinance 1984."

In the case of "Capital Assets Leasing Corporation Ltd V. International Multi Leasing Corporation Ltd”, it was held that "if the scheme of arrangement, amalgamation reconstruction or compromise is not workable, the court may order winding-up. This winding-up will be the winding-up mentioned under Section 305 of the Companies Act, 2017 ”.

\section{Grounds of Just \& Equitable Winding-Up}

Following are the situations in which court can make an order for dissolution of company on the ground of "just and equitable" which as under:

a) Court may pass an order for dissolution of company on "just and equitable" When court reached at the conclusion that object for which the company was incorporated became impossible as in case titled "PSO Co. Ltd. V. PAK. O.P. Ltd". The object of the company was violated. It is also called ultra vires to object clause. It was held by the court main object of the company is no more and ordered for dissolution of company on "just and equitable" ground to be wound-up.

b) When a situation arises where it is not possible for a company to carry on its business due to impossibility business and the real test will be seen by the court according to peculiar circumstances of company and may order for winding-up on "just and equitable ground."

c) Where the affairs and management of the company are not being carried out in interest of company as well as members and other stake-holders and the fraud then court may order for winding-up on just and equitable. Referring to the decision in "Ebrahimi v. Westbourne Gallaries Ltd". Court has maintained that it is wrong to create categories under which just and equitable clause is to be applied.

d) When it came on surface that business of the company is just like bubble which may be burst at any time. At this situation in order to save the public at large and other stake-holders it is safe for court to treat it a valid ground for winding up on "just and equitable ground". In case "London \& Country Coal Company", it was observed that the company in which it seems that there is no bona fide in the conduct of the directors to carry on the business properly then this fact is sufficient for dissolution of company on "just and equitable ground".

e) If the company is doing business in contravention to its object clause prescribed in memorandum, shareholders may apply to the court to restrain the doing of ultra vires business. In case "Amalgamated Syndicate”, the business for which the company was formed to carry out had come to an end but the director instead of settling the account, contemplated on starting another business, which was not within the objects of the company, the court made winding-up order under just and equitable clause.

f) In managements and affairs of company such situations arise when all stake-holders are not sailing in same boat and there is complete deadlock between the parties. The courts have in several cases expressed their view that a company may be wound up if the state of things is such that a deadlock has arrived in the management of the company. In case "Yanidje Tobacco Co", the company had only two shareholders, both were directors. A dispute between them arose which could not be resolved through arbitration. Court considered it a ground for "dissolution on just and equitable."

g) Directors are the most important members of a company and to some extent they have fiduciary relation with other members of the company. There are different approaches towards the nature of the duties of the 
directors in company`s affairs. Common law countries require a reasonable standard of care and skill of director towards its functions in company. Lack of confidence is a good ground for winding up company. In case titled "Davis v. Burnswick" it was held that lack of confidence in directors running the business of company is also a cause of winding-up on "just and equitable grounds."

h) If the company's business is running in loss, it is a ground to wind up the company. However, In "Davis v. Burnswick", it was observed that if there is a strong possibility for revival of business of the company and may come out of hot- waters and from depression, court should not order winding-up on just and equitable grounds.

i) In case "Anglo Continental Produce Co." it was observed that mere wish of the majority of the shareholder has to get their money back is no ground for just and equitable winding-up. If they wish to wind up, they must get $3 / 4$ majority.

j) Carrying on illegal business may be a sufficient ground for making a winding up order. Where according to object clause, the object was to conduct a business of gambling, violation thereof recommends winding up order.

k) Court law is not bound to follow the directions of majority shareholders. It is sole power of the court to see the actual circumstances of case and when main object is gone as held in case titled of "Fida Ali v. Graxalt Refineries". It was also observed that the winding-up order with respect of the company trying its best to reestablish its business is neither just nor equitable simply because a creditor has huge claim against company as he has other forums available to him to satisfy his claim. When substratum of company had disappeared and that it had failed to pay any interest on money and fact disclosed that company was not an association and not registered Company, winding up petition is not maintainable.

1) If the business of the company is carrying on for other not for those for whom the company was incorporated it may be a ground for winding-up on "just and equitable ground".

\section{Rescue Measures for Insolvent Companies In Pakistan}

A company concern can be considered as the lifeline of a society and country, as it is effective tool for employment, livelihood and wellbeing to its surrounding inhabitants. These entities become the source of economic prosperity, economic infrastructure, production and services ultimately contribute to the enhancement of national wealth. In fact prosperity of a company is the prosperity of a national wealth of a country, namely industrial health, employment generation, etc. The death of any of these capital generating entities will certainly have an adverse impact on the socioeconomic development of the country.

There should be efforts by the courts for safeguarding the corporate culture along with identification of weaknesses on part of the parties in order to provide guidelines.

In this respect, the role played by British Courts and Legislature particularly House of Lord in the development of principles of Company Law including Winding Up are very appreciable. It is also worth mentioning that corporate winding up developments also resulted into the creation of new discipline i.e. of accountancy. In other words accountancy discipline is offshoot of process of winding-up proceedings. In England the proceedings of winding-up were dealt with the Insolvency Act. For this purpose, amendments made in British Company Act 1985 in which all the procedure of winding-up was provided but subsequently due to the amendment this part of the company Act was inserted into the insolvency Act 1986. In USA, winding up proceedings are part of bankruptcy Chapter 11. There is a provision for financing of the company during the period it is under the protection of the chapter 11 of Bankruptcy. In South Africa, there is a concept of Judicial Management and in Singapore there is Scheme of Arrangement. All these are rescue plans for the rehabilitation of company which is under financial trouble.

So under the above scenario, it is rightly pointed out by Gower that when the company becomes insolvent and unable to pay his debt, it is put into the winding-up proceedings and ultimately it is dissolved. In other words it is put to end but in case of human being, he is also a natural legal person when he becomes insolvent or unable to pay his debt; he is not put to death. It is discrimination and unfair treatment as compared to natural person. This fact is very important that while dissolving any company all the possible efforts should be put in for the revival of the sick company and in this connection different steps have been taken by the different countries like South Africa, America and Singapore etc. in their legislations as mentioned above.

\section{Legislative development in Pakistan}


In Pakistan this sort of mechanism has been adopted in the shape of enactment of Corporate Rehabilitation Act, 2018 (CRA, 2018). The question arises whether this mechanism is sufficient for this purpose or not? Furthermore, how it can be considered as a positive step towards the protection of legal entities and sick industrial units in Pakistan? In addition to that, what possible ways could be adopted for better solution of facing financial difficulties by keeping in view the socio-economic scenario of Pakistan? These are the questions which will be discussed in the light of scheme of this enactment.

The new legislative mechanism introduced by parliament is a positive step towards the reorganization and better protection of corporate sector in Pakistan. A detailed procedure has been introduced in this Act regarding rehabilitation of financially sick and distressed company in order to make it a profitable entity which may helpful for the betterment of the economy of the country. A mechanism, in shape of appointment of insolvency expert, to deal with the technical financial matters, before going into the liquidation, has been introduced. The qualification of insolvency expert has also been laid down in law. The SECP shall maintain a panel of person well-versed in fields of accounting, finance, law, management and insolvency proceedings and practice in the country, with experience of 15 years in relevant field, in consultation with the State Bank of Pakistan (SBP).

The insolvency experts for their due performance and their functions under CRA 2018 will be entitled to remuneration and their code of conduct, appointment; training, capacity building and accreditation programs for professional development will be regulated by the SECP.

\section{Rehabilitation Plan for Debtors}

It is important that prior to this Enactment there was no specific procedure for rehabilitation of debtor in the country only creditors was person to be looked after but this law provided remedy debits to protect their right within fore corner of law.

A debtor shall be a company incorporated or registered under Ordinance or Act or previous company's legislation and shall not include:

A financial institution, an insurance company, a company with less than hundred mullions debits or as fortified by Federal in Official Gazette, from time to time, a company against whom, proceedings under section 17 CRA, 2018 have already initiated within five years, a company in favor of rehabilitation plan has already completed under CRA, 2018, a body corporate which resolved by special resolution to wind-up voluntarily and against whom winding-up order has been passed and otherwise.

Plan of rehabilitation shall specify the following matters in relation of debtor:

Claims and classes of claims against the debtor, interests and classes of interests in the debtor, claims and interests belonging to the debtor, interests and claims not covered by the plan, business place of debtor, details of debtor of its asserts any security interests created over asserts, particulars of members and key management and scheme of implementation of plan.

\section{Commencement of Case and Statement of Affairs:}

A debtor may file a petition in the court for an order of Mediation, which shall be supported by plan of rehabilitation of management of affairs and special resolution of the debtors approving the plan. The qualifying creditors may file a petition in the court for an order of mediation against a debtor. On first date of hearing, court shall issue notice to the parties listed in the petition through, "registered post, acknowledgement due, courier service and publication in one English and one Urdu daily newspapers of wide circulation in the country".

Notices shall specify date of hearing not later than 21days after service. Any person interested of filing written reply to the petition shall do so at least 3before the proceedings, who shall provide a copy of the reply to the other party who filed petition and court may, where a prime facie case has been made out by the qualifying creditor for an order of mediation in relation to a petition filed shall direct the debtor to submit, within " 15 days after submission of statement of affairs in the court". A qualifying debtor to submit statement of affairs and a plan of rehabilitation in court within is 30 days.

Introduction of mediation in corporate governance is a significant change in regulation of corporate activities in the country. it is most effective remedy for parities due to different reasons including cheaper and less time consuming. First of all court will issue the notice to the parties and after hearing the parties in petition filed under section 8 of CRA, 2018 pass an order for the appointment of insolvency experts to act as sole mediator or joint mediators as the case may be in relation to plan of rehabilitation filed in the court. The mediator appointed by the court shall carry out mediation between parties to achieve acceptance, with or without modification having certain powers under the law. 


\section{Appointment of Administrator:}

Apart from other mechanism provided by CRA, 2018 the appointment of administrator is also milestone in this regard it is positive step towards the protection capital of members of the company. Any qualifying creditor many file a petition before the court for appointment of administrator. It is power of the court to appoint the administrator before the confirmation of plan of rehabilitation keeping in view following reasons.

a. The affairs of business of company were conducted in a manner not favorable to the interest of debtor or qualifying creditors rather prejudicial.

b. Mismanagement, fraud, criminal breach of trust, misconduct was committed by the director or any authorizes person while managing affairs of the company.

c. Affairs of business have been conducted with intent defraud or for some fraudulent or unlawful purpose, to deprive the qualifying creditors from their claim, any project is not operated for more than two years, accumulative loss of debtor exceeding $60 \%$ of its paid up capital.

\section{Consequences of Nomination of Administrator:}

Once an administrator has been appointed by the court all previous powers of receiver, CEO, director will be ceased to exist with respect the property of debtor or otherwise directed by CRA,2018 shall remained continued till further order of the court. After the appointment of administrator all directors, debtors and management will support and provide cordial atmosphere for proper discharge of the duties of administrator. The entire previous managerial person will provide all available record, information, accounts, papers and books relating to debtors.

Powers of the administrator are to operate the debtor`s business, to prepare statement of affairs, where debtor has not done so, to investigate the acts, accounts, liabilities and financial conditions under the direction of the court.

a. Any investigation carried under this act can be used by administrator he can file statement in this regard.

b. He can accept, modify the rehabilitation plan submitted under this act or recommend the winding-up of the debtor.

c. In continuation of duties under this act he can file any suit or action and similarly defend the same or all legal proceedings against anybody under the law.

d. Be accountable for all the property of the debtor.

e. Subject to approval of administration committee, he is authorized to entering into any arrangement with creditors or persons claiming to be creditors.

f. He can provide information to interested parties after seeking permission from court of law.

g. Make and submit monthly reports, a final report and final accounts in the court.

h. He can perform any function in relation to the affairs of the debtor provide under the Act including appointment of members of administration committee.

\section{Problems and Weakness in Pakistan}

In Pakistan under Companies Act, 2017, apart from winding up modes there is also an alternative remedy in case of oppression and mismanagement. It is also called the minority shareholder's remedy on the ground that protection of minority shareholders is very difficult because they have less representation in management affairs of the company on other hand majority have the power to pass a resolution in the general meeting to protect their rights. In certain cases this remedy can be invoked by the majority shareholders due to different shareholding structures in Pakistan.

The remedies under oppressive conduct and just and equitable winding-up can be effective only when these are independent of each other. Winding-up is a costly remedy and is a death of the company that normally does not suit all the stakeholders including the petitioner. Mixing of both remedies with winging-up by the courts in Pakistan may be problematic and may create confusion. Other remedies should be the alternative of winding-up and these remedies should be feasible for minority shareholders in order to invoke the winding-up remedy as the last resort.

The remedies provided under Companies Act 2017, in case of insolvency and oppressive management by the majority shareholders are insufficient and outdated in the walk of new trends of the world and new corporate practice followed by developed nations. It is high time for making radical changes in the existing laws and regulations, particular in order to build the confidence of the foreign investors. Companies Ordinance is silent regarding the reorganization, restructuring, voluntary arrangement and other modes of rescue mechanism and rehabilitation of distressed corporations.

\section{Conclusion}

There are reason of dissolution of company are; failure to follow the rules and regulation insolvency, bankruptcy and unable to pay its outstanding debt. So we should frame such a mechanism which can provide assistance and aid to the 
companies facing insolvency in their financial matters. Global trends have been undergone a substantial change in corporate activities. Different jurisdictions have introduced various alternative corporate rescue methods to deal with the corporate insolvency and dispute between members, share-holders and other management. The introduction of Corporate Rehabilitation Act, 2018 is a positive step in Pakistan to gain the confidence of foreign investors and to provide a comfortable atmosphere of business activities to national as well international corporations. But this step is not sufficient to compete with the world having best corporate practices.

\section{References:}

Against whom execution petition is pending and which has availed the relief of BPD Circular No.29 of 2002 issued by SBP

Amalgamated Syndicate, Re, [1897]

Anglo- Continental Produce Co Ltd, [1939]

C A, 2017, S. 301(a)

C A, 2017, S 358.

C A, 2017, S 268

C A, 2017, S 275.

C A, 2017, S 309.

C A, 2017, S 439.

(Ali Woolen Mills Ltd v IDBP, [1989])

C A, 2017, S. 307, 308.

C A, 2017, S. 309

C A, 2017, S. 312

C A, 2017, S. 5

C A, 2017 S. 307

C A, 2017, S 402.

C A, 2017, S 405.

C A, 2017, S 305(h).

C A, 2017, S 314(2).

I A, 1986, S 125(2)

C A, 2017, S. 275.

C A, 2017, S. 305.

CRA, 2018, S, 7(1) (a-h.) 
Ibid, S, 7

Ibid, S, 10

CRA, 2018, S, 20

Ibid, S, 21

Ibid, S, 23

Ibid, S, 26

C A, 2017, S.290.

Ibid, 78

Companies Act 2017, s. 293.

Consolidated Exports Ltd v Dyer Textile and Printing Mills Ltd, [1984]

Davies, 1997

Davis \& Co Ltd V Brunswick Ltd, [1936]

Ebrahim V Westbourn Galleries Ltd, [1972]

Fida Ali Yousaf V Grazalt Refineries Ltd, [1967]

Fida Ali Yousaf V Grazalt Refineries Ltd, [1967]

Gupta, 2014

(HBL V Hamza Board Mills Ltd, 1996).

Integrated Technologies \& Systems Ltd V Interconnect Pakistan (Pvt) Ltd, [2001]

Messrs Adge Advertising Lahore V Messrs Shahzan International Ltd, [1970]

Messrs Industrial Development Bank of Pakistan vs Messrs Sarela Cement LTD Company, [1993]

Messrs Matito Ariba Industries Ltd vs Messrs Gammon Pakistan Ltd, [1997].

Messrs Matito Ariba Industries Ltd vs Messrs Gammon Pakistan Ltd, [1997].

Messrs Paltinum Insurace Company Ltd Karachi v Daewoo Corporation Sheikupura, [1999]

Messrs Paltinum Insurace Company Ltd Karachi v Daewoo Corporation Sheikupura, [1999]

Mrs. Suma Mahnaz Vayani and others V Molasses Export Company, [2013]

Mrs. Suma Mahnaz Vayani and others V Molasses Export Company, [2013]

Now this Ordinance has been repealed by Companies Act 2017.

Pakistan State Oil Company Ltd V Pakistan Oil Pipeline Ltd, [1993] 
Princess of Reuss V Boss [1871]

RAK Wr22231ight and R Buchany-dunlop, Palmer's Company Precedent (Steven \& Sons Limited 1960).

Re H R Harmer Ltd, [1959]

Re London and County Coal Co, [1866])

Re Yenidje Tobacco Co Ltd, [1916]

Rights and Duties of Directors 1, 1999

Rizvi and Rizvi Advocates Vs Walk orient power and Light Limited, [2002]

Shaukat Ali V Amin Fabric Ltd, [2008]

Sheikh Mazar Ali V Lasani Straw Board Mills (Pvt) Ltd, [2003]

Syndicate Bnak v Printersall P ITD [1991]

Trade and Industry publication Ltd v IDBP, [1990]

WAPDA V KAPCO, [2000]

Zahoor Kahn V Messers Shahabddin \& Sons, [1992]

Ibid, S, 5 